\title{
Assessment of IMCI Management of Undernutrition and Anemia in an Urban MCH Center; Assiut City
}

\author{
${ }^{1}$ Doaa M. Osman, ${ }^{2}$ Fatma' R. Khalaf, ${ }^{1}$ Doaa M. Abdel-Salam and ${ }^{3}$ Asmaa M. Ismail \\ ${ }^{1}$ Public Health and Community Medicine Department- Assiut University, ${ }^{2}$ Family and \\ Community Health Nursing Department - Assiut University, ${ }^{3}$ Pediatric department - \\ Aswan University
}

Received: April, 2018 Accepted: June, 2018

\begin{abstract}
Introduction: Since Integrated Management of Childhood Illnesses (IMCI) program was implemented as a part of child health services in Egyptian Ministry of Health, it has a well evident impact on reduction of childhood mortality. However, the details of IMCI management process have not been assessed. Objective: This study aimed to assess the IMCI management of undernutrition and anemia as well as knowledge and satisfaction of children care givers on provided services. Method: A cross sectional study was conducted in an urban maternal and child health center in Assiut city. An exit interview with the caregivers of 242 children who reported child undernutrition or anemia was administered. Results: The results revealed that, the most common child illnesses were as follow; anemia $84 \%$, and anemia with upper respiratory tract infection $12 \%$. Most of child's caregivers reported good performance of physicians regarding providing the diagnosis, prescribing the treatment and the way of giving it. However, child caregivers complained that the physicians missed the provision of a follow up schedule, type of feeding during illness and signs and symptoms indicated for immediate return to $\mathrm{MCH}$ center. Most of child caregivers had good knowledge about undernutrition and anemia. More than $90 \%$ of child caregivers were satisfied with the provided IMCI services. Conclusions and recommendation: The majority of child caregivers were satisfied with provided IMCI services. Health care providers should inform the child caregivers about the schedule of follow up, type of feeding during illness and signs and symptoms indicated for immediate return to $\mathrm{MCH}$ center.
\end{abstract}

Keywords: IMCI, Assessment, undernutrition and anemia, children care givers, Assiut city.

Corresponding auther: Doaa M. Abdel-Salam

Email: doodyas2004@yahoo.com

\section{Introduction}

Each year, about 11 million children die before reaching their fifth birthday. In response to this challenge, WHO and UNICEF in the early 1990s developed Integrated Management of Childhood Illness (IMCI), an approach designed to decrease child morbidity and deaths in under-developed countries. This strategy focuses on the major causes of deaths in children through improving case management skills of health workers, strengthening the health system, and addressing family and community practices. $^{1}$

The WHO/ UNICCF clinical guidelines for IMCI applied a standardized approach using simple and effective methods, this approach applied evidence-based assessment and treatment of sick child, concurrent with use of effective and low-cost medicine and simple equipment. ${ }^{2,3}$

The core of the IMCI strategy is integrated case management of the most common childhood problems; 
pneumonia, diarrhea, measles and malaria. ${ }^{4}$ The clinical guidelines include methods for assessing signs that indicate severe disease; assessing a child's nutrition, immunization, and feeding; teaching parents how to care for a child at home; counselling parents to solve feeding problems; and advising parents about when to return to a health facility. ${ }^{5}$ Childhood undernutrition is an important indicator of the health of a population. ${ }^{6}$ It is estimated that $56 \%$ of childhood deaths worldwide are attributable to the potentiating effects of undernutrition, with $83 \%$ of these arising from the mildto-moderate form rather than the severe form. ${ }^{7}$

Childhood undernutrition can have longterm physical and cognitive repercussions. The literature indicates that both fetal and childhood undernutrition have a marked effect on adult anthropometric outcomes. ${ }^{8}$ Furthermore, malnourished children display a reduced immune response compared with their well-nourished counterparts. This increases susceptibility to and mortality from communicable diseases ${ }^{9}$ conversely, such communicable diseases can also precipitate childhood undernutrition. ${ }^{10}$ WHO reported anemia as the world's second leading cause of disability and one of the most serious global public health problems. Anemia affects over half of pre-school children in developing countries and at least $30-40 \%$ in industrialized countries. ${ }^{11}$ It impairs cognitive and psychomotor development and the general health of children. ${ }^{12}$

Since IMCI introduction in Egypt in 1996, IMCI was adopted as a primary child health care program. IMCI coverage rose from $3 \%$ of primary health care facilities in 2000 to $98 \%$ in 2012 ; $95 \%$ of trained staff received a follow-up after training visit. ${ }^{13}$

Retrospective analysis, based on data from vital registration, assessed the impact of IMCI implementation between
2000 and 2006 on child mortality in 213 Egyptian districts. The analysis detected that IMCI implementation was associated with a doubling in the annual rate of under-five mortality reduction. ${ }^{14}$ World Health Organization considered Egypt as a successful model in IMCI implementation at national scale in a country with large population. ${ }^{13}$

To deliver high quality and affordable health services is considered difficult challenge. Health services researches are concerned with studying different aspects for health care services including; utilization, costs, quality, accessibility, delivery process, organization, financing, and outcomes. Health services researches has a value to inform providers themselves, consumers, governmental and non-governmental making decisions about health-related issues. ${ }^{15}$

The present study considered the earliest study assessing the process of IMCI management of undernutrition and anemia. Other aims of this study are assessing caregivers' knowledge about undernutrition and anemia, their satisfaction on provided services, and exploring the associated factors of undernutrition and anemia among children in urban maternal child center.

\section{Method:}

Setting: The study was carried out in an urban maternal and child health center in eastern area in Assiut city, Assiut Governorate; Upper Egypt. The selection of the center based on its application of IMCI management of children illness.

Study design: Descriptive crosssectional study design was applied.

Study population: Total coverage of children aged from 6 to 59 months and their caregivers who attend $\mathrm{MCH}$ center $(n=242)$ reported their children complaint of anemia or undernutrition and agreed to participate in the study. Data were collected by the researchers themselves by direct exit interviewing 
within 2-3 children caregivers per day on average in 6 months duration from February to July 2017. Response rate was $97 \%$, cause of children caregivers' refusal to participate in the study was no enough time. The data collection instrument was composed of 3 parts: The first part was interviewed administered questionnaire. The approximate time spent during the filling of the questionnaire was around 20-30 minutes from each child caregiver. The questionnaire included: (1) Socio-demographic characteristics such as child age, gender, residence and parent's education and occupation. (2) Process of IMCI assessment in management of undernutrition and anemia such as whether the physicians mentioned the diagnosis, prescribe treatment and explain to child care giver how to give treatment. Also, the process of IMCI assessment included whether the physician informs the care giver when to return for follow up and signs

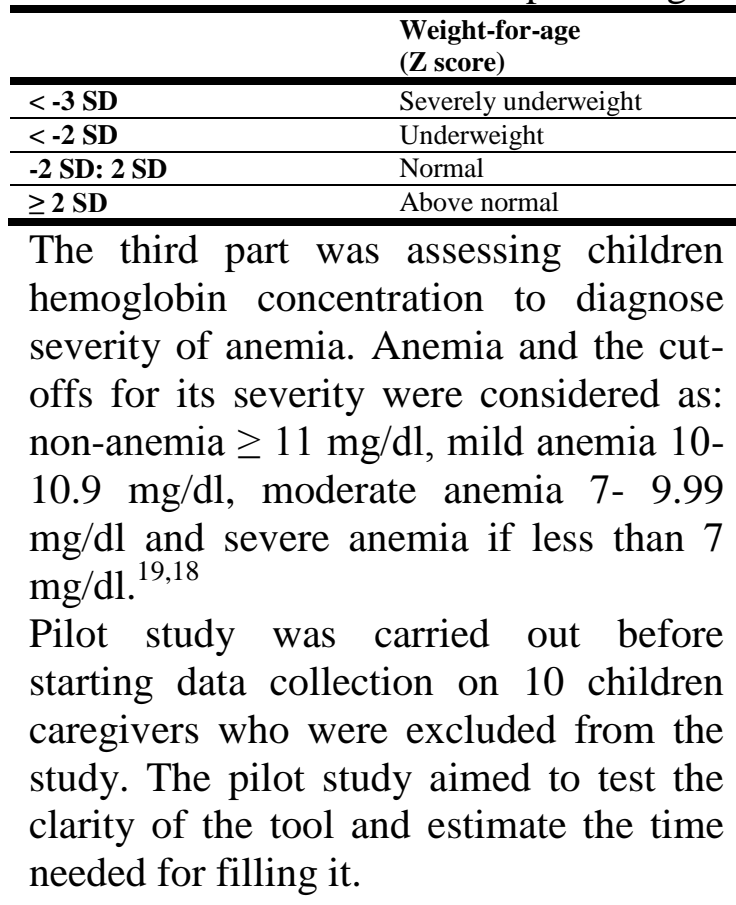

\section{Ethical consideration:}

Before the start of the study, the administrative approval to conduct the study was obtained from the Directorate of Health. The Ethical Committee, Faculty of Nursing in Assiut University and symptoms to return immediately. (3) Knowledge of children caregivers about anemia and undernutrition regarding causes, symptoms and complications. (4) Knowledge of children care givers about feeding pattern during illness and signs or symptoms indicated for immediate return to maternal and child health center. (5) Child caregiver satisfaction on the provided health services.

The second part was assessing the weight and height of studied children. Measurements were obtained from record performed by nurses responsible for IMCI program in the center. Nutritional status was classified based on the following indices: weight-for-age $\mathrm{z}$ score (WAZ), height- or length-for-age z-score (HAZ), and weight-for-height or length $\mathrm{z}$-score (WHZ) in accordance with the criteria proposed by $\mathrm{WHO}^{(16)}$ using the software WHO Anthro (version 3.2.2, January 2011) ${ }^{(17)}$ 


\section{Results:}

Table (1) shows that the mean of age of studied children was $17.7 \pm 9.5$ months and vast majority of children $(87.6 \%)$ were less than 2 years. Females constituted more than half of children $(52.1 \%)$. The majority of studied population (93.4\%) resides in urban area. About sixty percent of children parents had university education or above. Regarding fathers' occupation, professional workers represented $44.6 \%$ and employees $22.3 \%$. Nearly $59 \%$ of mothers were housewives.

Table (2) reveals that about $90 \%$ of children had their first visit to $\mathrm{MCH}$ center. The physician mentioned the diagnosis of child illness for $82.6 \%$ of children care givers. The most common child illnesses as reported by child caregivers were as follow; anemia $84 \%$, and anemia with upper respiratory tract infection $12 \%$. The physician prescribed treatment for $93.4 \%$ of children. Iron syrup was prescribed for $90.3 \%$ of children. The physician demonstrated the way of drug administration for $93.8 \%$ of studied sample. The physician or nurse mentioned for nearly $55 \%$ of caregivers when return to $\mathrm{MCH}$ for follow up visit. Among them, the physician or nurse told $7.5 \%$ of child caregivers to return after 14 days while majority of them $(91.0 \%)$ were informed to return after three months. More than two thirds of studied sample $(62.0 \%)$ was not counseled about type of child feeding during illness. The majority of studied sample $(86.8 \%)$ weren't informed about signs or symptoms indicated for immediate return to $\mathrm{MCH}$ center.

Figure (1) shows that the severity of anemia among studied children attended $\mathrm{MCH}$ based on assessed hemoglobin levels; more than half of children $(54.5 \%)$ were mild anemic while $45.5 \%$ of them were moderate anemic. No case was detected with severe anemia $(\mathrm{HB}<7$ $\mathrm{mg} / \mathrm{dl}$ )
Table (1): Socio-demographic characteristics of the interviewed caregivers and their children in urban MCH, Assiut 2017

\begin{tabular}{|c|c|c|}
\hline Item & $\begin{array}{l}\text { Total } \\
\text { No. } \\
(242)\end{array}$ & $\%$ \\
\hline $\begin{array}{l}\text { Age of the child (months) } \\
<2 \text { years } \\
\geq 2 \text { years up to } 5 \text { years } \\
\text { Mean } \pm S D \\
\text { (Range) }\end{array}$ & $\begin{array}{r}212 \\
30 \\
17.7 \\
\pm 9.5 \\
(6- \\
57)\end{array}$ & $\begin{array}{l}87.6 \\
12.4\end{array}$ \\
\hline $\begin{array}{l}\text { Gender: } \\
\text { Male } \\
\text { Female } \\
\end{array}$ & $\begin{array}{l}116 \\
126 \\
\end{array}$ & $\begin{array}{l}47.9 \\
52.1\end{array}$ \\
\hline $\begin{array}{l}\text { Residence: } \\
\text { Rural } \\
\text { Urban }\end{array}$ & $\begin{array}{r}16 \\
226\end{array}$ & $\begin{array}{r}6.6 \\
93.4\end{array}$ \\
\hline $\begin{array}{l}\text { Father education: } \\
\text { Illiterate / read \& write } \\
\text { Primary / preparatory } \\
\text { Secondary } \\
\text { University graduate/ } \\
\text { postgraduate }\end{array}$ & $\begin{array}{r}14 \\
14 \\
70 \\
144\end{array}$ & $\begin{array}{r}5.8 \\
5.8 \\
29.0 \\
59.4\end{array}$ \\
\hline $\begin{array}{l}\text { Father occupation: } \\
\text { Don't work } \\
\text { unskilled worker } \\
\text { skilled worker } \\
\text { Employee } \\
\text { Professional } \\
\text { Business worker } \\
\text { Died }\end{array}$ & $\begin{array}{r}2 \\
18 \\
32 \\
54 \\
108 \\
24 \\
4\end{array}$ & $\begin{array}{r}0.8 \\
7.4 \\
13.2 \\
22.3 \\
44.6 \\
9.9 \\
1.7\end{array}$ \\
\hline $\begin{array}{l}\text { Mother education: } \\
\text { Illiterate } \\
\text { Primary / preparatory } \\
\text { Secondary } \\
\text { University graduate/ } \\
\text { postgraduate }\end{array}$ & $\begin{array}{r}10 \\
12 \\
70 \\
150\end{array}$ & $\begin{array}{r}4.1 \\
5.0 \\
28.9 \\
62.0\end{array}$ \\
\hline $\begin{array}{l}\text { Mother occupation: } \\
\text { Housewife } \\
\text { Employee } \\
\text { Professional }\end{array}$ & $\begin{array}{r}142 \\
40 \\
60\end{array}$ & $\begin{array}{l}58.7 \\
16.5 \\
24.8\end{array}$ \\
\hline
\end{tabular}

Figure (2) illustrated that the proportions of wasted, underweight and stunted children were $5 \%, 4.1 \%$ and $12.4 \%$ respectively. The analysis showed no children were reported to have weight for age, height for age and weight for height less than 3 SD.

Table (3) reveals child caregiver knowledge about undernutrition and anemia. More than half of studied sample $(57.9 \%)$ was aware about undernutrition. About $57 \%$ of them reported the correct 
Table (2): Assessment of IMCI process by children care givers in urban MCH, Assiut, 2017

\begin{tabular}{|l|r|r|}
\hline Variable & No. (242) & \multicolumn{1}{|c|}{$\%$} \\
\hline Type of visit: & 216 & \\
$\quad$ First & 26 & 89.3 \\
Follow up & 200 & 10.7 \\
\hline Physician mention diagnosis for child caregivers: & 82.6 \\
\hline Child diagnosis reported by child caregivers: & 168 & \\
$\quad$ Anemia & 2 & 84.0 \\
$\quad$ Anemia \& low weight & 4 & 1 \\
$\quad$ Anemia \& rickets & 24 & 2 \\
$\quad$ Anemia \& upper respiratory tract infection & 2 & 12 \\
$\quad$ Parasitic infestation & 226 & 1 \\
\hline The physician prescribed a treatment for the child: & 93.4 \\
\hline Type of the treatment: & $\mathbf{N}=\mathbf{2 2 6})$ & \\
$\quad$ Iron & 204 & 90.3 \\
$\quad$ iron, antibiotic \& antipyretic & 20 & 8.8 \\
$\quad$ Irion \& Parasitic treatment & 2 & 0.9 \\
\hline The physician described the way of giving treatment & 212 & 93.8 \\
\hline The physician / nurse mention when to return for follow: up & 134 & 55.4 \\
\hline If yes duration: & $\mathbf{( N = 1 3 4 )}$ & \\
$\quad$ after 14 days & 10 & 7.5 \\
$\quad$ after 2 months & 2 & 1.5 \\
after 3 months & 122 & 91.0 \\
\hline Physician/ nurse mention type of feeding during illness: & 92 & 38.0 \\
\hline The physician/ nurse mention signs or symptoms indicated for immediate & 32 & 13.2 \\
return to MCH center: & 32 & \\
\hline
\end{tabular}

Table (3): Knowledge about undernutrition and anemia among child caregivers in urban MCH, Assiut, 2017

\begin{tabular}{|c|c|c|}
\hline Variables & No. (242) & $\%$ \\
\hline Knowledge of caregiver about definition of undernutrition & 140 & 57.9 \\
\hline Correct Symptoms of undernutrition & 80 & 57.1 \\
\hline \multicolumn{3}{|l|}{ Reported correct symptoms: * } \\
\hline Low weight & 46 & 57.5 \\
\hline Anorexia & 26 & 32.5 \\
\hline Delayed teething & 6 & 7.5 \\
\hline Decrease activity & 26 & 32.5 \\
\hline Correct Causes of undernutrition & 72 & 51.4 \\
\hline \multicolumn{3}{|l|}{ Reported correct causes: * } \\
\hline Unhealthy diet & 64 & 88.9 \\
\hline Parasitic infestation & 2 & 2.8 \\
\hline Mothers negligence & 8 & 11.1 \\
\hline Correct Complication of undernutrition & 92 & 65.7 \\
\hline \multicolumn{3}{|l|}{ Reported correct complication: * } \\
\hline Decrease immunity & 35 & 38.0 \\
\hline Delay growth & 40 & 43.5 \\
\hline Low effort & 24 & 26.1 \\
\hline Knowledge of caregiver about definition of anemia & 208 & 86.0 \\
\hline Correct Symptoms of anemia & 138 & 66.3 \\
\hline \multicolumn{3}{|l|}{ Reported correct symptoms: * } \\
\hline Pallor & 46 & 33.3 \\
\hline Low immunity/ repeated infection & 56 & 40.6 \\
\hline Affect intelligence & 10 & 7.2 \\
\hline Decrease activity & 37 & 26.8 \\
\hline Dark color under eye & 26 & 18.8 \\
\hline Correct Causes of anemia & 94 & 45.2 \\
\hline \multicolumn{3}{|l|}{ Reported correct causes: } \\
\hline Low iron in diet & 89 & 94.7 \\
\hline Parasitic infestation & 5 & 5.3 \\
\hline
\end{tabular}


Table (4): Knowledge regarding child feeding pattern during illness and danger signs among child caregivers in urban MCH, Assiut 2017.

\begin{tabular}{|l|r|r|}
\hline Variables & No. 242 & $\mathbf{\%} \mathbf{1 0 0}$ \\
\hline Child caregiver knowledge about breast feeding during illness: & 188 & \\
$\quad$ Continue feeding & 40 & 77.7 \\
Stop feeding & 14 & 16.5 \\
Don't know & & 5.8 \\
\hline Amount of feeding during illness: & 34 & \\
$\quad$ The same & 52 & 14.0 \\
Increased & 144 & 21.5 \\
Decreased & 12 & 59.5 \\
Don't know & & 5.0 \\
\hline Amount of fluids given during illness: & 20 & \\
$\quad$ The same & 202 & 8.3 \\
Increased & 16 & 83.5 \\
Decreased & 4 & 6.6 \\
Don't know & 154 & 1.7 \\
\hline The child caregiver Know about signs or symptoms indicated for & 63.6 \\
immediate return to MCH center? & & \\
\hline Child caregiver knowledge about signs or symptoms indicated for & & \\
immediate return to MCH center: $*$ & 116 & 75.3 \\
Fever & 30 & 19.5 \\
Progress of illness & 16 & 10.4 \\
Vomiting & 12 & 7.8 \\
Diarrhea & 10 & 6.5 \\
\hline Unable to drink or feed & & \\
\hline
\end{tabular}

symptoms of undernutrition. The most frequent reported symptom of undernutrition $(57.5 \%)$ was low weight. The proportion of children care givers identified correct causes of undernutrition was $51.4 \%$. The main cause of undernutrition reported by nearly $90 \%$ of child caregivers was unhealthy diet. More than two thirds of studied population $(65.7 \%)$ was aware about complication of undernutrition. The most common complications of undernutrition reported were delayed growth (43.5\%), decrease immunity (38\%).

The table also revealed that $86.0 \%$ of care givers knew about anemia. Regarding symptoms of anemia; more than two thirds of them (66.3\%) mentioned correct answers. Most frequent mentioned symptoms of anemia in order were Low immunity with repeated infection and pallor. Nearly $45 \%$ of child caregivers identified the correct causes of anemia and low iron in diet was the commonest reported causes $(94.7 \%)$

Table (5): Satisfaction of child caregivers on provided IMCI service in urban MCH, Assiut 2017

\begin{tabular}{|l|r|r|}
\hline Variables & No. 242 & \% \\
\hline Satisfaction: & & \\
$\quad$ Very satisfied & 124 & 51.2 \\
Satisfied & 104 & 43.0 \\
Dissatisfied & 14 & 5.8 \\
\hline Causes of satisfaction:* & No.= (228) & \\
Waiting time & 44 & 19.3 \\
Dealing of heath team worker & 162 & 71.1 \\
Quality of child examination & 68 & 29.8 \\
Manner of physician communication & 56 & 24.6 \\
Prescribed treatment & 24 & 10.5 \\
\hline Causes of dissatisfaction: & No. =(14) & \\
Waiting time & 2 & 14.3 \\
Way of communication with physician & 10 & 71.4 \\
Prescribed treatment & 2 & 14.3 \\
\hline
\end{tabular}

Table (4) depicts the knowledge of during illness; more than three quarters children care givers about child feeding $(77.7 \%)$ of child caregivers reported that 
breast feeding should be continued. About $60 \%$ of child caregivers mentioned that the amount of feeding during illness should be decreased while 83.5\% recommended increasing amount of fluids during illness. Nearly $64 \%$ of caregivers knew signs or symptoms indicated for immediate return to $\mathrm{MCH}$

Table (6): Relationship between socio-demographic, knowledge score, severity of anemia and undernutrition among children in urban MCH, Assiut 2017

\begin{tabular}{|c|c|c|c|c|c|c|c|c|c|}
\hline \multirow[b]{2}{*}{ Variables } & \multicolumn{2}{|c|}{ Wasting } & \multirow[b]{2}{*}{$P$ value } & \multicolumn{2}{|c|}{ Underweight } & \multirow{2}{*}{$\begin{array}{c}\mathbf{P} \\
\text { value }\end{array}$} & \multicolumn{2}{|c|}{ Stunting } & \multirow{2}{*}{$\begin{array}{c}\mathbf{P} \\
\text { value }\end{array}$} \\
\hline & $\begin{array}{l}\text { Present } \\
\text { No. (12) }\end{array}$ & $\begin{array}{c}\text { Absent } \\
\text { No. }(230)\end{array}$ & & $\begin{array}{l}\text { Present } \\
\text { No. (10) }\end{array}$ & $\begin{array}{c}\text { Absent } \\
\text { No. (232) }\end{array}$ & & $\begin{array}{l}\text { Present } \\
\text { No. (30) }\end{array}$ & $\begin{array}{c}\text { Absent } \\
\text { No. (212) }\end{array}$ & \\
\hline $\begin{array}{l}\text { Child age } \\
\text { Mean } \pm \text { SD }^{\alpha}\end{array}$ & $14.5 \pm 3.06$ & $17.85 \pm 9.69$ & 0.518 & $20.60 \pm 14.11$ & $17.56 \pm 9.27$ & 0.853 & $22.467 \pm 11.6$ & $17.01 \pm 8.9$ & 0.001 \\
\hline $\begin{array}{c}\text { Gender } \\
\text { Male } \\
\text { Female }\end{array}$ & $\begin{array}{l}4(33.3) \\
8(66.7)\end{array}$ & $\begin{array}{l}112(48.7) \\
118(51.3)\end{array}$ & 0.229 & $\begin{array}{r}10(100.0) \\
0(0.0)\end{array}$ & $\begin{array}{l}106(45.7) \\
126(54.3)\end{array}$ & $\begin{array}{r}0.001 \\
\circledR\end{array}$ & $\begin{array}{l}18(60.0) \\
12(40.0)\end{array}$ & $\begin{array}{r}98(46.2) \\
114(53.8)\end{array}$ & 0.185 \\
\hline $\begin{array}{c}\text { Residence } \\
\text { Rural } \\
\text { Urban }\end{array}$ & $\begin{array}{r}0(0.0) \\
12(100.0) \\
\end{array}$ & $\begin{array}{r}16(7.0) \\
214(93.0) \\
\end{array}$ & 0.344 & $\begin{array}{r}0(0.0) \\
10(100.0) \\
\end{array}$ & $\begin{array}{r}16(6.9) \\
216(93.1) \\
\end{array}$ & $\begin{array}{r}1.000 \\
(\circledR) \\
\end{array}$ & $\begin{array}{r}0(0.0) \\
30(100.0) \\
\end{array}$ & $\begin{array}{r}16(7.5) \\
196(92.5) \\
\end{array}$ & $\begin{array}{r}0.232 \\
\text { ( }\end{array}$ \\
\hline $\begin{array}{l}\text { Father education } \\
\text { Illiterate / read \& } \\
\text { write } \\
\text { Primary / } \\
\text { preparatory } \\
\text { Secondary/upper } \\
\text { intermediate } \\
\text { University or } \\
\text { education } \\
\text { more }\end{array}$ & $\begin{array}{l}0(0.0) \\
2(16.7) \\
4(33.3) \\
6(50.0)\end{array}$ & $\begin{array}{r}14(6.1) \\
12(5.2) \\
6628.7) \\
138(60.0)\end{array}$ & $0.309 a$ & $\begin{array}{l}0(0.0) \\
2(20.0) \\
2(20.0) \\
6(60.0)\end{array}$ & $\begin{array}{r}14(6.0) \\
12(5.2) \\
68(29.3) \\
138(59.5)\end{array}$ & $0.209 a$ & $\begin{array}{r}0(0.0) \\
4(13.3) \\
10(33.3) \\
16(53.3)\end{array}$ & $\begin{array}{r}14(6.6) \\
10(4.7) \\
60(28.3) \\
128(60.4)\end{array}$ & $0.122 a$ \\
\hline $\begin{array}{l}\text { Mother education } \\
\text { Illiterate / read \& } \\
\text { write } \\
\text { Primary / } \\
\text { preparatory } \\
\text { Secondary/upper } \\
\text { intermediate } \\
\text { University or } \\
\text { education on } \\
\text { more }\end{array}$ & $\begin{array}{l}2(16.7) \\
0(0.0) \\
2(16.7) \\
8(66.7)\end{array}$ & $\begin{array}{r}8(3.5) \\
12(5.2) \\
68(29.6) \\
142(61.7)\end{array}$ & $0.106 a$ & $\begin{array}{r}2(20.0) \\
0(0.0) \\
0(0.0) \\
8(80.0)\end{array}$ & $\begin{array}{r}8(3.4) \\
12(5.2) \\
70(30.2) \\
142(61.2)\end{array}$ & $0.015 a$ & $\begin{array}{r}2(6.7) \\
2(6.7) \\
6(20.0) \\
20(66.7)\end{array}$ & $\begin{array}{r}8(3.8) \\
10(4.7) \\
64(30.2) \\
130(61.3)\end{array}$ & $0.615 a$ \\
\hline $\begin{array}{l}\text { Father occupation } \\
\text { Don't work } \\
\text { unskilled/ } \\
\text { Skilled worker } \\
\text { Employee } \\
\text { Professional / } \\
\text { Business worker } \\
\text { Died }\end{array}$ & $\begin{array}{l}2(16.7) \\
2(16.7) \\
6(50.0) \\
2(16.7) \\
0(0.0)\end{array}$ & $\begin{array}{r}0(0.0) \\
48(20.9) \\
48(20.9) \\
130(56.5) \\
4(1.7)\end{array}$ & $0.000 \mathrm{a}$ & $\begin{array}{r}2(20.0) \\
0(0.0) \\
4(40.0) \\
4(40.0) \\
0(0.0)\end{array}$ & $\begin{array}{r}0(0.0) \\
50(21.6) \\
\\
50(21.6) \\
128(55.2) \\
4(1.7) \\
\end{array}$ & $0.000 \mathrm{a}$ & $\begin{array}{r}2(6.7) \\
6(20.0) \\
8(26.7) \\
14(46.7) \\
0(0.0)\end{array}$ & $\begin{array}{r}0(0.0) \\
44(20.8) \\
46(21.7) \\
118(55.7) \\
4(1.9) \\
\end{array}$ & $0.004 a$ \\
\hline $\begin{array}{c}\text { Mother occupation } \\
\text { House wife } \\
\text { Employee } \\
\text { Professional }\end{array}$ & $\begin{array}{l}6(50.0) \\
4(33.3) \\
2(16.7)\end{array}$ & $\begin{array}{r}136(59.1) \\
36(15.7) \\
58(25.2) \\
\end{array}$ & $0.265 a$ & $\begin{array}{l}2(20.0) \\
4(40.0) \\
4(40.0)\end{array}$ & $\begin{array}{r}140(60.3) \\
36(15.5) \\
56(24.1) \\
\end{array}$ & $0.029 a$ & $\begin{array}{r}18(60.0) \\
4(13.3) \\
8(26.7)\end{array}$ & $\begin{array}{r}124(58.5) \\
36(17.0) \\
52(24.5) \\
\end{array}$ & 0.874 \\
\hline $\begin{array}{l}\text { Knowledge* Mean } \pm \\
\text { SD } \\
{ }^{\alpha}\end{array}$ & $4.67 \pm 1.78$ & $4.12 \pm 2.17$ & 0.392 & $4.7500 \pm 1.16$ & $4.1261 \pm 2.17$ & 0.224 & $4.79 \pm 1.81$ & $4.06 \pm 2.19$ & 0.094 \\
\hline $\begin{array}{l}\text { Severity of anemia } \\
\quad \text { Mild } \\
\text { Moderate }\end{array}$ & $\begin{array}{l}6(50.0) \\
6(50.0)\end{array}$ & $\begin{array}{l}126(54.8) \\
104(45.2)\end{array}$ & 0.378 & $\begin{array}{l}6(60.0) \\
4(40.0)\end{array}$ & $\begin{array}{l}126(54.3) \\
106(45.7)\end{array}$ & 0.359 & $\begin{array}{l}16(53.3) \\
14(46.7)\end{array}$ & $\begin{array}{r}116(54.7) \\
96(45.3)\end{array}$ & 0.079 \\
\hline
\end{tabular}

Chi-square test $\quad$ RFisher's Exact test $\quad \alpha$ Exact test $\quad \alpha$ Mann-Whitney U test *Parents only who were included $(\mathrm{n}=230)$

satisfied/satisfied about provided services. The most common reported causes of satisfaction were dealing of health team worker $(71.1 \%)$ and quality center. The most frequent reported symptoms indicated for immediate return to $\mathrm{MCH}$ center were fever $(75.3 \%)$, progress of illness $(19.5 \%)$ and vomiting $(10.4 \%)$

Table (5) revealed that the majority of children caregivers (94\%) were very 


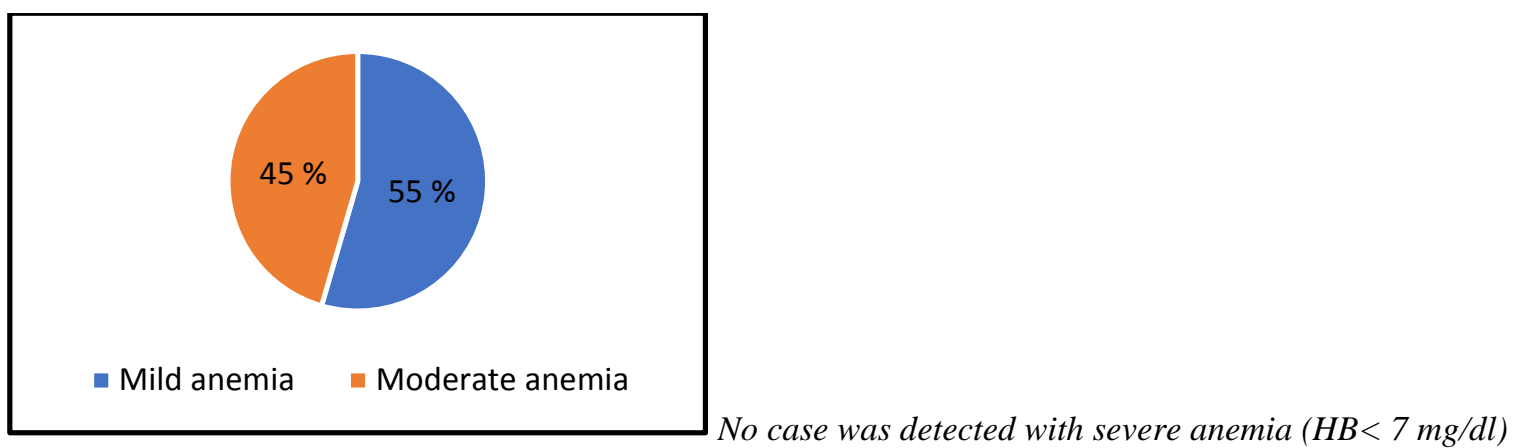

Figure (1): Distribution of severity of anemia among studied children in urban MCH, Assiut 2017

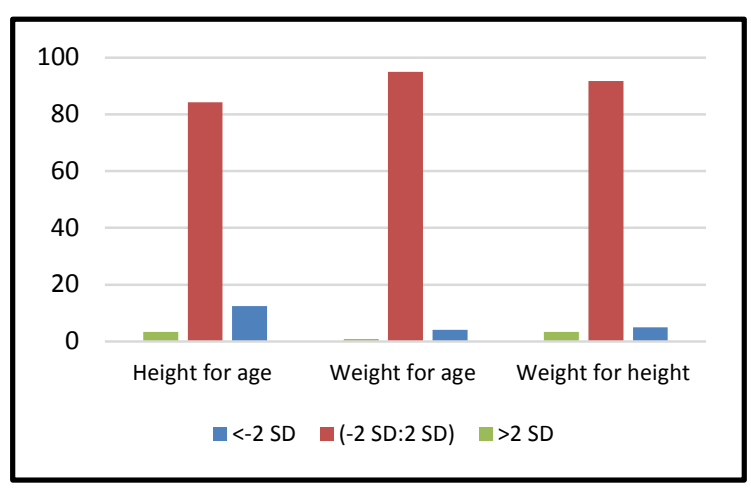

No children were reported to have either weight for age, height for age or weight for height less than $3 S D$.

Figure (2) Distribution of nutritional indices among studied children in urban MCH, Assiut 2017

children have significantly higher mean of age $(22.467 \pm 11.63)$ compared to nonstunted ones $(17.01 \pm 8.98)(\mathrm{P}$ value $=0.001)$. Gender was significantly related to underweight as males had significantly higher proportion compared to females $(\mathrm{P}=0.001)$. Significant higher proportion of underweight children was detected in children whose mothers had university education or above $(80 \%)$ and in working mothers $(80 \%)$. father' occupation was significantly associated with wasting, underweight and stunting ( $\mathrm{P}$ value $<0.05)$.

\section{Discussion:}

IMCI follow simple techniques that save lives of children, it provides better management of sick children at low cost to municipalities. Compared to previous vertical disease specific programs, it addresses integrated management of most killer childhood diseases undernutrition and anemia. ${ }^{20}$

To ensure the continuous efficiency of health programs, assessment for their operating process is necessary. Assessment of IMCI was conducted either in small scale as assessment of specific item in the program e.g. health care providers counseling for children caregivers in a cross-sectional study using quantitative and qualitative methods In Uganda ${ }^{21}$, or large scale as national assessment of all component of IMCI program using different tools as analysis of routine statistics, surveys on health care providers and children caregivers sought health care, and stakeholders over 10 years duration in the Republic of Moldova. ${ }^{22}$ The current study assessed the IMCI management process for undernutrition and anemia through exist interview with children care givers.

Undernutrition is highly prevalent among children in low and middle-income countries. However, wide variations exist in the overall prevalence of underweight, stunting, and wasting among children across countries. ${ }^{23-26}$ Results of Egyptian Demographic Health Survey, 2014 (EDHS) showed that among children under 5 years, Overall, nearly $27 \%$ of children suffered from variable degree of anemia. Also, 21\%, 8.4\% and 5.5\% of children had stunting, wasting and underweight respectively. It showed that undernutrition was higher in urban Upper Egypt where prevalence of stunting was about $30 \%$, wasting was $9 \%$ and underweight was $8.1 \% .^{27}$

In the present study, the proportions of stunting, wasting and underweight were 
$12.4 \%, 5 \%$ and $4.1 \%$, respectively. However, the proportions of undernutrition indicators in present study cannot be generalized as these results are limited to similar studied population whose children caregivers sought care and complained from low weight or anemic presentation.

Based on hemoglobin assessment, all cases in the current study suffered from either mild or moderate anemia. Similar finding was observed in EDHS, 2014 results. ${ }^{27}$

In the current study, the majority of children caregivers reported that physician prescribed a treatment for their children and informed them with the correct way of giving treatment. This was in line with IMCI basic guidelines that stated prescription of treatment and provision caregivers with practical treatment instructions e.g. how to give oral drugs at home. ${ }^{28}$

A basic component of IMCI management process is counseling the care givers about how to feed and give fluids during illness. $^{28}$ Provision of accurate and timely information help to decrease burden of children undernutrition. ${ }^{29}$ In the present study, although all children were anemic with detected proportion of undernourished children, about two thirds of children caregivers reported that the physician or nurse did not inform them about child feeding and nutrition at home. While better practice of health providers in IMCI program was observed In Uganda. Where, using direct observation revealed that $76 \%$ of health providers gave feeding advices. ${ }^{21}$

Regarding informing caregivers on time of follow up visit, IMCI stated that if pallor was detected, follow-up visit should be after 14 days and if low weight for age was noticed, the follow-up advised to be after 30 days. $^{30}$ In this study, nearly $55 \%$ of children caregivers were informed when to return for follow up visit, among those who were informed to return, only $7.5 \%$ of them were asked to return after 14 days, and $92.5 \%$ were advised to return for follow up visit after two or three months that exceed the appropriate date of follow up.

Informing children caregivers about reasons necessitate immediate return to unit is a basic component of IMCI. In the present study, the majority (87\%) reported that the physician did not mention this item for them. While in Uganda, good performance of health care providers was observed in this item $(78 \%)^{21}$

Regarding caregivers' satisfaction on provided IMCI services in management of undernutrition and anemia, dealing of heath care team and quality of child examination were the most frequent reported aspects of satisfaction in the present study. These results agreed with those of national IMCI assessment in Moldova showed that the most common mentioned reasons were communication of physicians and child management services. $^{22}$

In the present study, most of caregivers (63.6\%) knew about signs or symptoms indicated for immediate return to $\mathrm{MCH}$ center. The mentioned symptoms were fever $(75.3 \%)$, progress of illness $(19.5 \%)$, persistent vomiting $(10.4 \%)$ and the child inability to drink or feed (6.5\%). However, Moldavian children caregivers had better knowledge than current study. Where, about $88.5 \%$ of them were able to list at least two danger signs indicated for immediate return. The most often known signs were fever over $38 \mathrm{C}(90.5 \%)$, child vomits everything $(48.9 \%)$, worsening condition $(46.3 \%)$ and child is unable to drink or eat $(44.7 \%)^{22}$

Regarding mother's knowledge on undernutrition in this study, about 58\% acknowledged prior knowledge of undernutrition and $51 \%$ of them reported correct causes of undernutrition such as unhealthy diet, mother negligence and parasitic infestation. This finding was not in line with WHO that reported that poor 
hygienic condition, poverty and unsafe water can lead to undernutrition in children $^{31}$ and study conducted by Cumber and his colleagues showed that $73 \%$ of the mothers were aware of undernutrition and the reported causes of undernutrition by these mothers were poor hygienic condition in preparing the child's food, poverty, unsafe water diseases and infections. ${ }^{32}$

Regarding caregivers' knowledge about anemia, $86 \%$ of them were aware about its definition. Low immunity, repeated infection and pallor were the common correct symptoms of anemia reported by the caregivers. The majority of caregivers reported low iron in diet as the main cause of anemia. These results disagree with a study conducted in Tanzania revealed that more than half of mothers $(55 \%)$ have heard about anemia. The most frequent symptoms of anemia reported by the mothers in Tanzania were pallor of conjunctiva and reduced physical activity and the main causes of anemia were frequent illness, and refusal to eat. ${ }^{33}$

Breastfeeding reduces infant mortality due to common childhood illnesses such as diarrhea or pneumonia and helps for a quicker recovery during illness. ${ }^{34}$ More than three quarters of children caregivers in the present study correctly answered that the breast feeding should be continued during illness. Similar finding was detected in Indian study evaluated knowledge of mothers on breast feeding, where $82 \%$ of studied sample mentioned that breast feeding should be continued during illness. ${ }^{35}$

Stunting was significantly associated with higher child's age in the present study. This is consistent with other studies carried out in Ethiopia ${ }^{36}$, Ghana ${ }^{37}$ and India ${ }^{38}$. This could be attributed to decreasing immune protective effects of breast milk in older children with mixed, or even absence of breastfeeding, coupled with increasing exposure to contaminated supplementary foods, resulting in the increase probability of infectious diseases along with growing need for nutrients, compared to younger children who might be protected by the mother's immune system at birth. ${ }^{39}$

Stunting in the present study was significantly associated with professional fathers in contrast with other studies which showed its association with irregular employment status of father. $^{26,40,41}$ Mother education has protective role against child undernutrition. ${ }^{42}$ However, the present study showed that underweight was significantly associated with highly educated mothers and working mothers. This might be explained by that employed mothers had limited time to give care to their children compared to unemployed mothers. ${ }^{43}$

The present study showed that male children were more likely to be underweight than female counterparts. This is consistent with other studies. ${ }^{44,45}$ However, it contradicts other studies. ${ }^{46,47}$ This could be explained by boys are more affected by environmental stress than girls. Thus, boys are more likely to exhibit chronic undernutrition effect. ${ }^{48}$

\section{Conclusion:}

Most of child caregivers were satisfied with provided IMCI services. Children caregivers reported good performance of physicians regarding telling the diagnosis, prescribing the treatment. Also, they had good knowledge about undernutrition and anemia.

\section{Recommendations:}

To ensure providing efficient IMCI services, health care providers should give emphasis to child caregivers about when to return for follow up, type of feeding during illness and signs and symptoms indicated for immediate return to $\mathrm{MCH}$ center.

\section{Acknowledgment:}

We acknowledge children care givers for their participation in the study, health care team in the studied $\mathrm{MCH}$ center for 
their cooperation with researchers, and for Professor Dr Ekram Mohamed Abed El Khalek Professor of Public Health in Assiut Faculty of Medicine.

\section{References:}

1. Tigest Ketsela PH, Jose Martines,Andrew Mbewe,Abimbola Williams,, Jesca Nsungwa Sabiiti AT, Indira Narayanan, Rajiv Bahl Opportunities for Africa's Newborns:Practical data, policy and programmatic support for newborn care in Africa. World Health Organization; 2006; Available from: http://www.who.int/ pmnch/media/publications/aonsectionIII_5.p df.

2. Sallam SA, El-Mazary A-AM, Osman AM, Bahaa MA. Integrated Management of Childhood Illness (IMCI) Approach in management of Children with High Grade Fever $\geq 39^{\circ}$. International Journal of Health Sciences. 2016;10(2):239-48.

3. WHO. Maternal, newborn, child and adolescent health: Integrated Management of Childhood Illness (IMCI). 2018; Available from: http://www.who.int/maternal_child _adolescent/topics/child/imci/en/.

4. WHO. Maternal, newborn, child and adolescent health: IMCI chart booklet: World Health Organization; 2014.

5. WHO, UNICEF. Handbook: IMCI integrated management of childhood illness. 2005.

6. Ezzati M, Lopez AD, Rodgers A, Vander Hoorn S, Murray CJ. Selected major risk factors and global and regional burden of disease. Lancet. 2002;360(9343):1347-60.

7. Pelletier DL, Frongillo EA, Jr., Schroeder DG, Habicht JP. The effects of undernutrition on child mortality in developing countries. Bull World Health Organ. 1995;73(4):443-8.

8. Karlberg J, Luo ZC. Foetal size to final height. Acta Paediatr. 2000;89(6):632-6.

9. Fergusson P, Tomkins A. HIV prevalence and mortality among children undergoing treatment for severe acute undernutrition in sub-Saharan Africa: a systematic review and meta-analysis. Trans R Soc Trop Med Hyg. 2009;103(6):541-8.

10.Ehrhardt S, Burchard GD, Mantel C, Cramer JP, Kaiser S, Kubo M, et al. Malaria, anemia, and undernutrition in african children--defining intervention priorities. J Infect Dis. 2006;194(1):108-14.

11.WHO. Anaemia prevention and control. World Health Organization; 2018; Available from: http://www.who.int/medical devices /initiatives/anaemia_control/en/.

12.UNICEF UNU, and WHO. Iron deficiency anaemia : assessment, prevention, and control : a guide for programme managers / [United Nations Children's Fund, United Nations University, World Health Organization].2001.

13.WHO. Egypt IMCI experience: a systematic approach for implementation 2017; Available from: http://www. emro.who.int/child-adolescent-health/imci/ egypt-imci-experience-a-systematicapproach-for-implementation.html.

14. Rakha MA, Abdelmoneim A-NM, Farhoud S, Pièche S, Cousens S, Daelmans $B$, et al. Does implementation of the IMCI strategy have an impact on child mortality? A retrospective analysis of routine data from Egypt. BMJ Open. 2013;3(1).

15.Steinwachs DM, Hughes RG. Health services research: Scope and significance:Patient Safety and Quality: An Evidence-Based Handbook for Nurses. 2008. 16.WHO. Global Database on Child Growth and Undernutrition. World Health Organization; 2018; Available from: http://www.who.int/nutgrowthdb/about/intro duction/en/index 5. html.

17.WHO. Child growth standards; WHO Anthro (version 3.2.2, January 2011) and macros. World Health Organization; 2018; Available from: http://www.who.int/ childgrowth /software/en/.

18. WHO. Haemoglobin concentrations for the diagnosis of anaemia and assessment of severity. World Health Organization: World Health Organization; 2011.

19.IBM. SPSS Statistics for Windows. Version 20.0 ed. Armonk, NY: IBM Corp 2011.

20.Amorim DG, Adam T, Amaral JJ, Gouws E, Bryce J, Victora CG. Integrated Management of Childhood Illness: efficiency of primary health in Northeast Brazil. Rev Saude Publica. 2008;42(2):183-90.

21.Karamagi CAS, Lubanga RGN, Kiguli S, Ekwaru PJ, Heggenhougen K. Health Providers' Counselling of Caregivers in the Integrated Management of Childhood Illness 
(IMCI) Programme in Uganda. African Health Sciences. 2004;4(1):31-9.

22.Laur E, Officer M. Evaluation of Integrated Management of Childhood Illnesses Initiative in the Republic of Moldova Years 2000-2010.

23.Abdelaziz SB, Youssef MRL, Sedrak AS, Labib JR. Nutritional Status and Dietary Habits of School Children in Beni-Suef Governorate, Egypt. Food and Nutrition Sciences. 2015;6(01):54.

24. Bhoite $R$, Iyer $U$. Magnitude of undernutrition and iron deficiency anemia among rural school children: An appraisal. Asian J Exp Biol Sci. 2011;2(2):354-61.

25.Mukudi E. Nutrition status, education participation, and school achievement among Kenyan middle-school children. Nutrition. 2003;19(7-8):612-6.

26. Oninla SO, Owa JA, Onayade AA, Taiwo

O. Comparative Study of Nutritional Status of Urban and Rural Nigerian School Children. Journal of Tropical Pediatrics. 2007;53(1):39-43.

27.El-Zanaty EMOHP, ICF Demographic and Health Survey 2014 Ministry of Health and Population [Egypt].: Ministry of Health and Population Cairo, Egypt and Rockville, Maryland, USAand ICF International. 2015. 28.WHO, UNICEF. Handbook : IMCI integrated management of childhood illness : World Health Organization. Dept. of Child and Adolescent Health and Development\& UNICEF. Geneva: World Health Organization; 2005.

29.Paintal K, Aguayo VM. Feeding practices for infants and young children during and after common illness. Evidence from South Asia. Maternal \& Child Nutrition. 2016;12(Suppl Suppl 1):39-71.

30.WHO. WHO Library Cataloguing-inPublication Data: Integrated Management of Childhood Illness: distance learning course,Module 6; Undernutrition and anemia: World Health Organization 2014.

31.WHO. WHO Child Growth Standards: Length/height-for-age, weight-for-age, weight-for-length,weight-for-height and body mass index-for-age Methods and development. Geneva: World Health Organization; 2006.

32.Cumber SN, Ankraleh N, Monju N. Mothers' knowledge on the effects of undernutrition in children 0-5 years in Muea health area Cameroon. Journal of Family Medicine and Health Care. 2016;2(4):36.

33.Ngimbudzi EB, Lukumay AM, Muriithi AW, Dhamani KA, Petrucka PM. Mothers' Knowledge, Beliefs, and Practices on Causes and Prevention of Anaemia in Children Aged 6-59 Months: A Case Study at Mkuranga District Hospital, Tanzania. Open Journal of Nursing. 2016;6(04):342.

34.WHO. Maternal, newborn, child and adolescent health : breast feeding. World Health Organization 2018; Available from: http://www.who. int/ maternal_ child_adolescent/topics/ child/nutrition/ breastfeeding/en/.

35.Sriram S, Soni P, Thanvi R, Prajapati N, Mehariya K. Knowledge, attitude and practices of mothers regarding infant feeding practices. National Journal of Medical Research. 2013;3(2):147-50.

36. Yimer G. Undernutrition among children in southern Ethiopia: Levels and risk factors. Ethiopian Journal of Health Development. 2000;14(3).

37.Colecraft EK, Marquis GS, Bartolucci AA, Pulley L, Owusu WB, Maetz HM. A longitudinal assessment of the diet and growth of malnourished children participating in nutrition rehabilitation centres in Accra, Ghana. Public Health Nutr. 2004;7(4):487-94.

38.Kumar D, Goel NK, Mittal PC, Misra P. Influence of infant-feeding practices on nutritional status of under-five children. Indian J Pediatr. 2006;73(5):417-21.

39.Cruz LMG, Azpeitia GG, Suarez DR, Rodriguez AS, Ferrer JFL, Serra-Majem L. Factors Associated with Stunting among Children Aged 0 to 59 Months from the Central Region of Mozambique. Nutrients. 2017;9(5).

40.Abdel Wahed WY, Hassan SK, Eldessouki R. Undernutrition and Its Associated Factors among Rural School Children in Fayoum Governorate, Egypt. Journal of environmental and public health. 2017;2017.

41.Adegun J, Ajayi-Vincent O, Alebiosu E. Differences in the nutritional status of young school children from public and private owned primary schools in Ekiti state, Nigeria. European Scientific Journal, ESJ. 2013;9(7).

42. Mittal A, Singh J, Ahluwalia S. Effect of maternal factors on nutritional status of 1-5- 
year-old children in urban slum population. Indian Journal of Community Medicine. 2007;32(4):264.

43. Khattak UK, Iqbal SP, Ghazanfar H. The Role of Parents' Literacy in Malnutrition of Children Under the Age of Five Years in a Semi-Urban Community of Pakistan: A Case-Control Study. Cureus. 2017;9(6).

44.Glascoe FP. Parents' concerns about children's development: prescreening technique or screening test? Pediatrics. 1997;99(4):522-8.

45.Hien NN, Hoa NN. Nutritional status and determinants of undernutrition in children under three years of age in Nghean, Vietnam. Pak J Nutr. 2009;8(7):958-64.
46.Benjamin AI, Zachariah P. Nutritional status and feeding practices in under- 3 years old children in a rural community in Ludhiana, Punjab.Health and PopulationPerspectives and Issues. 1993;16(1\&2):3-21. 47.Joseph B, Rebello A, Kullu P, Raj VD. Prevalence of undernutrition in rural Karnataka, South India: a comparison of anthropometric indicators. J Health Popul Nutr. 2002;20(3):239-44.

48. Olack B, Burke H, Cosmas L, Bamrah S, Dooling K, Feikin DR, et al. Nutritional status of under-five children living in an informal urban settlement in Nairobi, Kenya. J Health Popul Nutr. 2011; 29 (4): 357-63. 